\title{
Understanding Students' Learning Outcomes Differences Through the Application of the Market Place Activity Type of Cooperative Learning Model and the Application of Conventional Learning Models
}

\author{
Evita Evita $^{1^{*}}$, Ahmad Syahid ${ }^{2}$, and Nurdin Nurdin ${ }^{3}$ \\ ${ }^{1}$ Islamic Education Department, Postgraduate, Institut Agama Islam Negeri Palu \\ ${ }^{2}$ Islamic Education Department, Postgraduate, Institut Agama Islam Negeri Palu \\ ${ }^{3}$ Islamic Education Department, Postgraduate, Institut Agama Islam Negeri Palu
}

\section{ABSTRACT}

This study aims to examine the learning outcomes differences through the application of the market place activity type of cooperative learning model and conventional learning models in Islamic Education subjects in Elementary Schools. The method used is quasi-experimental research (a method that has a control class but may not work fully to control the external variables that affect the experiment). The result of the first research indicates that there aredifferences in the students' learning outcomes through the application of market place activitytype of cooperative learning models and the application of conventional learning models in Islamic Education subjects. This can be seen from the value of sig. (2tailed) of $0.00<0.05$. Second, there are differences in students' learning outcomes through the application of market place activitytype of cooperative learning modelsand the application of conventional learning models in Islamic Education subjects at SDN Binangga 1. This can be seen from the value of sig. (2tailed) of $0.02<0.05$. The third study found differences in learning outcomes of students through the application of market place activitytype of cooperative learning models and the application of conventional learning models in Islamic Education subjects at SDN 1 Binangga. This can be seen from the sig. (2-tailed) value of $0.00<0.05$.The implications of this research are expected to be valuable reference and information for educators to be more creative and innovative in implementing learning models so that the material provided will be more easily understood by students.
ARTICLE

INFORMATION

Keywords:

Learning Outcomes, Islamic Education, Cooperative Learning Model, Conventional Learning Model, Differences 


\section{Pendahuluan}

Education isessentialfor human in developing themselves optimally. As intelligent beings, humans are created to always learn from the beginning of birth until he returns to the Creator.

Education is very important for the progress of a country. The progress of a country is largely determined by the advancement and management of education. Education in Indonesia aims to improve the quality of Indonesian people as a whole. Therefore, humans not only need knowledge and skills, but also ability to think rationally, critically and creatively.

Education is a conscious and planned effort to create learning atmosphere and learning process wherethe students can actively develop their potential to have spiritual strength, self-control, personality, intelligence, noble character, and the skills needed for themselves, society, nation and country. ${ }^{1}$

The teaching and learning process is the core of school education activities. For the purpose of education and learning to run properly, it is necessary to administer teaching and learning activities which are commonly called curriculum administration.Learning activities involved two main characters, teachers and students. Teacher'saction is teaching and student's is

${ }^{1}$ Undang-undangSistemPendidikanNasional No. 20 Tahun 2003 learning. Teaching and learning activities are related to learning materials which can be in the form of knowledge, moral values, art, religion, attitudes and skills. Many experts have conducted research on good and appropriate methods for students.They concluded that the existing learning models can be modified, re-tested and developed, then applied in learning activities based on the learning patterns used and their suitability with the learners' characters.

In the implementation of learning activities, many terms are used to describe the teaching methods performed by the teacher, various learning strategies and methods that aim to improve the quality of learning. In the world of education, the terms model, approach, strategy, method, technique and tactics are very familiar but sometimes confusing educators.Learning models that have been developed include Student Teams Achievement Division (STAD), Jigsaw, Picture and Picture, Number Head Together, Think Pair Share (TPS), Teams Game Tournaments (TGT), Team Assisted Individualization (TAI), and Make a Match.

In effective and meaningful learning, the students are actively involved because they are the center of learning activities as well as competencies and characters formation. The learning model is closely related to students' learning styles and 
teaching styles of teachers. Therefore, the teachers' effort in teaching including selectingapproppriate methods, strategies, techniques and learning models is a very important part in achieving the success of the planned learning goals.

Based on the experts' opinions above, the researchers concluded that Learning model is a pattern or planning that is designed to create effective and efficient learning process to achieve the learning objectives. The many variations of learning modelsare used to improve the quality of learning in the classroom. Learning models have many variations.

To achieve the learning objectives, developing conducive classroom environment is an obligation for teachers in order that the students interested in attending Islamic Education lesson. The indicators are students being active in learning process and listening attentively to the teacher's explanations.

However, the reality shows that the students become less attentive on the subject matter delivered by the teacher. This is because the learning strategies used in learning Islamic Education are not appropriate and effective.

A quality learning is characterized by an effective learning process which gives meaningful impression to students resulted in subject matter comprehension improvements and learning objectives can be achieved. To find out the achievement of learning objectives, it is necessary to evaluate learning outcomes. Assessment of learning outcomes according to Regulation of the Minister of National Education No. 20 of 2007 can be seen from the block exam, midterm, semester exam, school exams, and national exam.

The low learning outcomes are influenced by various factors both from within and from outside. Factors coming from within students include health, disability, intelligence, attention, interests, attitudes, talents, motives, maturity, and readiness, while from outside of students include family environment, school environment, and society.

The school environment has a considerable influence in improving students' learning outcomes, one of which is by applying creative and innovative learning models so that students feel interested and continue to follow the lesson. Learning models that are often and practically used by teachers in teaching and learning are presentations, direct learning, concept learning, cooperative learning, problem based learning, and class discussion. There is no single model the best among others. All learning models have their strengths and weaknesses, therefore teachers must be able to consider the most appropriate model to 
facilitate students in achieving learning objectives and understanding the material provided.

The case found in SDN 1 Binangga is the teacher merely provides material without considering good and appropriate methods used in the learning process. The consequence is decreased concentrationand achievement of the learners.

Theoretically, the Market Place Activity learning model draws students closer to learning to discover the concept of the lesson independently and connects between material learned and daily life experiments which will encourage students to think critically, creatively and with excitement. The growth of attitudes and feelings to explore and examine things related to the subject matter of the provisions of salat will further increase the students' learning achievement. In the application of Market Place Activity, tolerance values can also be instilled, through the attitude of serving other groups who visit their stands.

\section{Literature Review}

\subsection{Previous Research}

Research journals and methods in education on behalf of Munawaroh entitled the Effect of the STAD Type of Cooperative Learning Model, Learning Methods, and Learning Motivation towards
Entrepreneurial Attitudes (Case Study at SMK N 1 Jombang). This approach is known as STAD type of cooperative learning. The research employed quasiexperimental method. The sample chosen were 38 students of III AP1, 39 students of III AK 3, and 35 students of III PJ 1, taken randomly. The data collected were analyzed using ANOVA and Multiple Linear Regression. Based on the test results, it was found that1) ANOVA $F$ is 17,855 and. 000 sig, indicating the sig count value is less than 0.05 , which means there is an average difference between the experimental group and the control group (the experimental group is the group that gets the STAD type of cooperative learning model and the control group is the group that does notget the STAD type of Cooperative Learning), therefore there is no influence of the STAD type of Cooperative Learning towards entrepreneurship attitude.2) regression test results obtained with t-value 2.473 to 0.014 sig, indicating the value of sig. less than 0.05 , which means there is a learning effect on entrepreneurial attitudes.3). Regression test results obtained with t-values 0.871 and $0.384 \mathrm{sig}$ indicate that the calculated sig value is greater than 0.05 , which means there is no influence of learning motivation on entrepreneurial attitudes.4) the test results obtained ANOVA $F$ value of 2.734 and $0.100 \mathrm{sig}$, indicating the sig value calculated 
is greater than 0.05 , which means there is no average difference between the experimental group and the control group, therefore there is no influence of the STAD type of cooperative learning model on learning mode 5) the regression test results obtained with $t$ values of 5.314 to $0,000 \mathrm{sig}$, show the sig count value is less than 0,05 which means there is an influence of learning on learning motivation. 6) the test results obtained an ANOVA F value of 0.180 and $0.672 \mathrm{sig}$, sig shows that the calculation is greater than 0.05 , which means there is no average difference between the experimental group and the control group (ie the experimental group is the group that gets the type of cooperative learning model STAD and the control group are groups that do not get the STAD type of cooperative learning model, so there is no influence of the STAD type Cooperative Learning Model on learning motivation.Based on the results of the Multiple Linear Regression Test obtained with an $\mathrm{F}$ value of 8,847 to $0,000 \mathrm{sig}$, indicating the sig value calculated is less than 0.05 , which means there is a simultaneous influence of the STAD model of cooperative learning on motivation to learn entrepreneurial attitudes. ${ }^{2}$

\footnotetext{
${ }^{2}$ Munawaroh, The Effect of Type Stad Cooperative Learning Model, the Way of Learning, And Learning Motivation toward Enterpreneurial Attitudes (A case Study in SMK N I Jombang), (Journal of Research \& Method in Education (IOSR-
}

Research entitled "The Effect of Market Place Activity Learning Model on Students' Achievement in Junior High School of PGRI 1 Cimahi City". This research employed quasi experimental research. The population of this research were students of class VII in SMP PGRI 1 Cimahi. The class that was used as the experimental group was $7 \mathrm{G}$ class consists of 36 students and 35 people of $7 \mathrm{H}$ as the control class. Data collection techniques use questionnaires, tests, and interviews. The instruments to measure learning achievement are pre-test and post-test in the form of objective tests. In the experimental group, the mean score of pre-test 1 was 58.3 and the post-test score was 75.1. In the control group, the mean score of pre-test 1 was 64.1 and the post-test 1 score was 68.1. Whereas the experimental group obtained an average pre-test 2 of 76.5 and post-test of 79.5. In the control group obtained an average pre-test 2 of 62.4 and post-test value of 74.4 Hypothesis test results showed that the significance value of $0.76>0.05$ for the questionnaire, the results of the pre-test normality test were 0.185 and post The test was 0.558 , the pre-test homogeneity test was 089 and the post-test was 0.919 . From these results it can be concluded that the use of Market place activity learning models has a

JRME), Volume 3, Issue 5, Nov. Dec. 2013), PP 3844 
positive effect on student achievement in PKN lesson of class VII SMP PGRI 1 Cimahi City. ${ }^{3}$

Research with the title "Application of Market Place Activity (MPA) Method on the Competence of salat Provisions". The purpose of the research is to find out the improvement in activity and learning outcomes through the application of the MPA method in the subject of salat provisions in grade IV students of SD N Jembayat 01. This research is a classroom action research which was held for 2 cycles. The results showed that the improvement of learning through the application of the MPA method in pre-cycle scores an average of 58 with a percentage of $26 \%$, in the first cycle rose $39 \%$ with an average class of 71 , and at the end of the second cycle, the class average reaches 78 with completeness $82 \%$, so it is said to be complete classically. Learning improvement activities are categorized as good, with an average value in the first cycle of 63.8 and in the second cycle an increase reaching average value of 75.3 means increased to good by using the MPA method.The results showed that the improvement of learning through the application of the MPA method in pre-cycle

${ }^{3}$ EdySofyandanSantyVirgantyani.Pengaruh Model Pembelajaran Market Place Activity TerhadapPrestasiBelajarSiswa Di SMP PGRI 1 Kota Cimahi.(Jurnalilmiah CISOC. Vol. IV No. 02), 115129 scores an average of 58 with a percentage of $26 \%$, in the first cycle rose $39 \%$ with an average class of 71 , and at the end of the second cycle the class average reaches 78 with completeness $82 \%$, so it is said to be complete classically. Learning improvement activities are categorized as good, with an average value in the first cycle of 63.8 and in the second cycle an increase reaching average value of 75.3 means increased to good by using the MPA method. ${ }^{4}$

The first research had similarities about cooperative learning models but differs in type, students behavior and data analysis used. The second has the similarity of Market Place Activity learning models on Learning Achievement but differs in terms of data analysis. While the third research has similarities in Market Place Activity learning models but differ on the salat competence and data analysis used.

\subsection{Cooperative Learning Model}

Abdurrahman and Bintaro said that "Cooperative learning is a learning that is consciously and systematically develops interactions that educate, love, tolerate each other (silihasah, silihasihdansilihasuh) as an

\footnotetext{
${ }^{4}$ Fatmawati.PenerapanMetode Market Place Activity (MPA) PadaKompetensiKetentuanSholat. (JurnalPenelitianPendidikan Indonesia Vol. 2, No. 2: 1-6), h. 1-6
} 
exercise in living in a real society. ${ }^{5}$ Robert

Slavinalso said that cooperative learning is a learning model where students learn and collaborate in small groups whose members consist of 4 to 6 people, with a heterogeneous group structure. The success of learning in groups depends on the abilities and activities of group members, both individually and in groups. ${ }^{6}$

Artzt and New man define Coooperative learning is an approach that involves a smallgroup of learners working together as a team to solve a problem, complete a task, or accomplish a common goal. ${ }^{7}$ The cooperative learning model is a learning model that helps students develop their understanding and attitudes in accordance with the needs of the community, so that working together among fellow group members will increase learning motivation, productivity and outcomes of students.

a. Characteristics of Cooperative Learning The characteristics of cooperative learning are:

1) Students work in groups cooperatively to complete learning material. The group is

\footnotetext{
${ }^{5}$ NurhadidanAgusGeradSenduk, Pembelajaran KonstektualdanPenerapannyadalamKBK,(Malang:U niversitasNegeriMalang,2003), h. 59-60

${ }^{6}$ EtinSolihatindanRaharjo,CooperatifLearning AnalitisModelPembelajaranIPS,(Jakarta:PTBumiAk sara,2007), h. 4

${ }^{7}$ Asma,ModelPembelajaranKooperatif,(Jakart a:DirekturJendralPendidikanTinggiDirekturatKetena gaan,2006), h. 11
}

formed from students with high, medium and low abilities. Where possible, group members come from diverse races, cultures, ethnicities, genders. Appreciation is more group oriented than individual. $^{8}$

b. Basic Elements of Cooperative Learning

The basic elements of cooperative learning according to Lungdren are as follows:

Students are required to have the perception that they "sink or swim together". In addition to being responsible for themselves in dealing with the material they learn, they hold responsibilities for other students in the group.

1) The students must view that they have the same goal.

2) Students share tasks and responsibilities among group members. Students are given an award or evaluation that will influence the group evaluation.

3) Students share leadership while they acquire the skills to work together in learning.

4) Every student is account for a material handled individually in the cooperative group. ${ }^{9}$

By taking into account the elements of cooperative learning, the conclude that in

\footnotetext{
${ }^{8}$ Trianto,MendesainModelPembelajaranInovat ifProgresif,(Surabaya:Kencana, 2009), 65-66

${ }^{9}$ Isjoni,CooperatifLearning,(EfektifitasPembel ajaranKelompok),(Bandung: Alfabeta,2010),14.
} 
cooperative learning every student participated in a group must be able to establish cohesiveness. In addition, responsibilities are not only in the group, but also individual responsibility.

c. The Objectives of Cooperative Learning

The main purpose in applying the cooperative learning model in teaching and learning is that students can learn in groups with their friends by respecting each other's opinions and providing opportunities for others to express their ideas by expressing opinions in groups. ${ }^{10}$

According to Slavin there are three central concepts characterized cooperative learning: ${ }^{11}$

1) Group awards

Group awards are obtained if the group reaches a score above the specified criteria. The success of a group is based on the individual's appearance as a group member in creating interpersonal relationships that support one another, help one another and care for one another.

\section{2) Individual Responsibility}

The success of a group depends on the individual learning of all group members. The responsibility focuses on the activities of group members who help each other in learning. The existence of individual

\footnotetext{
${ }^{10}$ Ibid, 21

${ }^{11}$ RoberE.Slavin, CoperativeLearning:Teori,Ri set,danPraktik,(Bandung:Nusa Media 2009), 10
}

accountability makes each member ready to do tests and assignments independently without the help of the group.

3) Equal opportunity to success

Cooperative learning uses a scoring method which measures the students' improvements based on achievement obtained by each student compared to the previous state. With this scoring method, every student who has a low, medium, or high achievement has the opportunity to succeed and do the best for the group learning.

\section{d. Steps of Cooperative Learning}

The steps or phases of the cooperative learning model include:

1) Delivering goals and motivating students

2) Delivering information

3) Organizing students into learning groups

4) Monitoring groups of students and guiding where necessary

5) Evaluating and giving feedback and awards.

e. Strengths and Weaknesses of Cooperative Learning

$$
\text { Cooperative learning has some }
$$
advantages and weaknesses as follows:

1) The strengths of cooperative learning: First, improving individual and group skills in problem solving. Second, increasing commitment. Third, eliminating prejudice against peers. and Fourth eliminating a sense of revenge. 
2) The weaknesses of cooperative learning: First, in completing a lesson using cooperative learning requires relatively longer time. Secondly, inexperienced teacher cannot adjust the material to the curriculum. Thirdly, high-achieving students will lead to disappointment. Fourth, high-skilled learners feel disappointment when they must help their low-ability friends. ${ }^{12}$

\subsection{Market place activity}

Cooperative learning model is a learning model in which conditions the students to work together in small groups to help one another in learning. Cooperative learning is based on the idea or thought that students work together in learning and are responsible for their group learning activities as for themselves. Cooperative learning is one of the learning models that embraces constructivism.Constructivism approach in teaching specifically makes extensive cooperative learning, in theory students will be easier to find and understand difficult concepts through discussing with their peers. $^{13}$

Cooperative learning is a model that prioritizes collaboration between students to achieve learning goals. It changes learning into student-centered. While MPA is a

\footnotetext{
${ }^{12}$ NurAsma,ModelPembelajaran, .26-27

${ }^{13}$ Sutikno, M. Sobry, h. 57
}

learning method in the form of market activities, where students conduct buying and selling information activities. Each group of students has the information to sell to the other groups. The information traded in each group is the material learned on that day. Eachgroup understands the concept of information they are going to sell through discussion then formulate a concept of work or media that will be easily understood by prospective buyers who will visit the group. ${ }^{14}$

Market Place Activity (MPA) is a type of cooperative learning which focus on learning by working together in groups, where each group member cooperates with one another in buying and selling information. Cooperative learning or cooperative learning is placing several students in small groups and assigning them one or several tasks. ${ }^{15}$

In the application of Market Place Activity, intrinsic values can also be instilled when students visit group stand each other. Tolerance values are instilled through the attitude of serving other groups who visit. ${ }^{16}$

This learning technique with MPA contains a nurturing effect in building characters directly, such as being responsible

\footnotetext{
${ }^{14}$ EdySofyandanSantyVirgantyani.Pengaruh, h. 117

${ }^{15}$ Aunurrahman.BelajardanPembelajaran. (Bandung :Alfabeta. 2009), h. 45-65 $\mathrm{C}$

${ }^{16}$ Fatmawati.Penerapan, h. 2
} 
for making and maintaining his work, working in groups, being open to buyers' criticism, working hard to be the best, accustomed to evaluating and being evaluated, building independence, selfconfidence, teamwork skill, receiving feedback and learning to be responsible in making the best planning and design, as well as many values contained in the learning.

The stages of preparation in conducting a market place activity cooperative learning model are:

Divide students with small groups of between 4-10 people adjusted to class conditions, either by counting according to the seat or distributed colorful paper, colorful markers, candy with different brands according to the desired group. We suggest doing group formation with colorful paper / markers, different candies to make them accustomed to being different. It can build the strength and solidarity to the group.

Students sit in groups by moving the seats into small groups either $\mathrm{U}, \mathrm{O}$ or round table formation or they are grouped outside the classroom by sitting on the ground, then let them recognize each other in a short amount of time. Try to have their seats designed so that they can easily move and visit from one group to another.

Students in each group elect the group leader and secretary for example by asking all participants to appoint the expected leader in the count of three, then continue to choose the secretary, or by playing music in the background and when it stops, they point out to the expected chairperson and secretary.

After selecting the chairman and secretary, each group agreed on the group name in accordance with the subject matter, for example when the lesson is about Akhlak then the name of the group can be Honest, Empathy, Istiqomah, Caring, Hard work and so on. When the lesson is faith, the names of angels can be used, etc.

The teacher explains the purpose and the scope of the material to be discussed, giving clarity to students about what to do, as well as what instruments to be used in the learning process. those can be done less than 5 minutes.

The teacher shares the content of the groupdiscussion. It can be the same if the extent of the material is very limited. When it is very broad, then the material for each group is arranged differently adjusted to the name of the group. ${ }^{17}$

Then, proceed to the implementation of learning methods as follows:

In this stage the teacher as a facilitator monitors each group by checking the progress of group discussions and providing

\footnotetext{
${ }^{17}$ http://www.google.com/amp/s/jorjoran.wo rdpress.com/2016/11/10/implementasi-teknikmarket-place-activity-mpa-learning/amp. aksespadatanggal 5 mei 2018
} 
assistance when there are complicated problems. If students sit on the ground, the teacher should also sit when giving answers or assistance to students in order to be more familiar with students.

Each group conducts discussionrelated to the content their group is responsible for by learning from a variety of sources, textbooks, worksheets, previous interview results, magazines, newspapers, internet and so on. the results of the discussion are then set out in a clear group work and designed to be easily understood by other groups, whether in the form of concepts, pictures, caricatures, charts, tables or stages of a concept based on scientific references that can be justified.

When the group work is finished and ready to be traded on the market, each group divides the task of who will be a buyer to another group by bringing product assessment instruments prepared by the teacher and a small note and who will be a silent seller in the group welcoming prospective buyers from the other group.

The seller explains the prominence of his product in detail while those who function as buyers will visit other groups to see, buy, assess by noting important points, ask the seller, and provide comments as proof of purchasing, for example by giving signatures, stars or coins prepared by the teacher beforehand.
The buyer of each group visits the other groups' display for approximately 5-6 minutes and notes important things explained by the seller of the group visited. The teacher should prepare a stopwatch to count the time of visit to each group so that buyers do not gather up in one group.Changing of visit follows the clockwise or vice versa.

After visiting all groups, the buyer returns to his group, reporting the results of his visit. The buyer explains to thesellers in his group, then make assessment and discuss it together. The seller explains the input and suggestions from other group buyers, then summarizes the findings and input for the improvement of their group work, especially the important points.

Each group, then, presents the improvement of their work maximally 2 minutes each group, or minimally explain the comments from other groups while collecting the results of peer assessments previously distributed by the teacher. If time is very limited, only the representation from several groups considered the best will perform.

The teacher do reflection by reviewing what happens in the learning process in relation to the learning objectives and the character values recorded. The group's best results are announced transparently. It is highly recommended to give rewards in the 
form of gifts, praise, stars or a kind of simple trophy.

The teacher do reinforcement about the material by explaining theoretical and conceptual studies as well as evidences related to the material in the form of displays, videos, and stories, then connecting them with some contexts which can be easily understood by students according to their age, for example connecting existing realities in society with ideal condition that should be existed based on education.

The teacher together with the students concludes the learning material, and closes the learning activities by singing together, praying and reading hamdalah and greetings. ${ }^{18}$

\subsection{Conventional Learning}

The conventional learning model is a term that is used for daily learning activities model. The model tends to focus on memorization learning and exercises in texts. In addition, the assessment is still in the form of paper and pencil tests, which only requires one correct answer. The steps of this model generally start from explaining the material provided by the teacher, doing the exercises given and ending with homework assignments. ${ }^{19}$

\footnotetext{
${ }^{18}$ Ibid

${ }^{19}$ Widiana,I.Wayan;Jampel,I.Nyoman “Learn ingModelandFormofAssesmenttowardtheInferensialSt atisticalAchievementby
}

The following are several reasons why conventional learning models frequently used and also the advantages: ${ }^{20}$

a. The teacher can easily control the class.

b. Easy to organize seats or classes

c. Can be followed by a large number of students.

d. Easy to prepare and implement.

e. The teacher can easily explains the lesson well.

However, the conventional learning models also have weaknesses. They are: ${ }^{21}$

a. It is easy for verbalism to occur.

b. Facilitating auditory learners, but not visual learners.

c. The class will be boring.

d. The teacher concludes that the students understand and are interested in his class.

\section{Research Methodology}

The researcheremployed quantitative approach.The method used is quasiexperimental research (a method that has a control class but may not work fully to control the external variables that affect the experiment). ${ }^{22}$ The researchers collected data

ControllingNumericThinkingSkills”,

(InternationalJournalofEvaluationandResearchin Education(IJERE), Volume.5,Nomor2tahun2016)h. 137

${ }^{20}$ MuhibbinSyah,PsikologiPendidikandengan PendekatanBaru,(Bandung:PTRemaja Rosdakarya,2007),h. 100

${ }^{21}$ Ibid,h. 101

${ }^{22}$ Sugiyono.,

MetodePenelitianKuantitatifKualitatifdan $R \& D$.

Bandung : Alfabeta, 2012), h. 79 
using research instruments then analyzed the statistical data to test the hypothesis.

The method used in this study is a type of research design with the posttestonly control group design method. The first group was given treatment $(\mathrm{X})$ and the other group was not. The treated group is called the experimental group and the untreated group is called the control group. ${ }^{23}$ In this treatment the experimental and control groups were not chosen randomly.

The effect of treatment is symbolized by (O2: O4).Seeing the effect of treatment based on its significance using $t_{\text {test }}$ statisticswhich is then processed using the help of a Statistical Product and Service Solution (SPSS) computer program.If there is a significant difference between the experimental group and the control group, it means that the given treatment has a significant effect. For more details about the research design used in this research, it can be seen in the picture below:

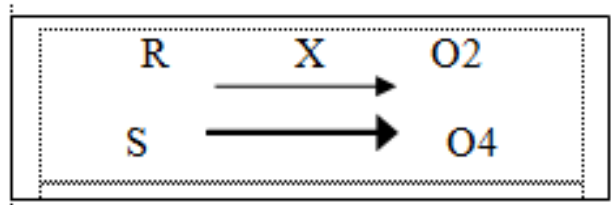

Keterangan:

$$
\begin{array}{ll}
\mathrm{R} & =\text { Experimental class }(\mathrm{VA}) \\
\mathrm{S} & =\text { control class }(\mathrm{VB}) \\
\mathrm{X} & =\text { Treatment } \\
\mathrm{O} 2 & =\text { posttest results of the experimental } \\
& \text { class } \\
\mathrm{O} 4 & =\text { posttest result of control class }
\end{array}
$$

${ }^{23}$ Ibid., h. 76
The sampling technique used in this study is the purposive sampling, where the sample selected based on certain considerations. ${ }^{24}$ The sample of this research is 40 fifth grade students. The number is divided into two, control class and experimental class.

\section{Result and Discussion}

\subsection{Experimental Class}

In experimental class, the research was conducted by applying the market place activity type of cooperative learning model in the VA class and then it was assessed using post test consist of 5 essay questions. The results are describe in the frequency table as follows:

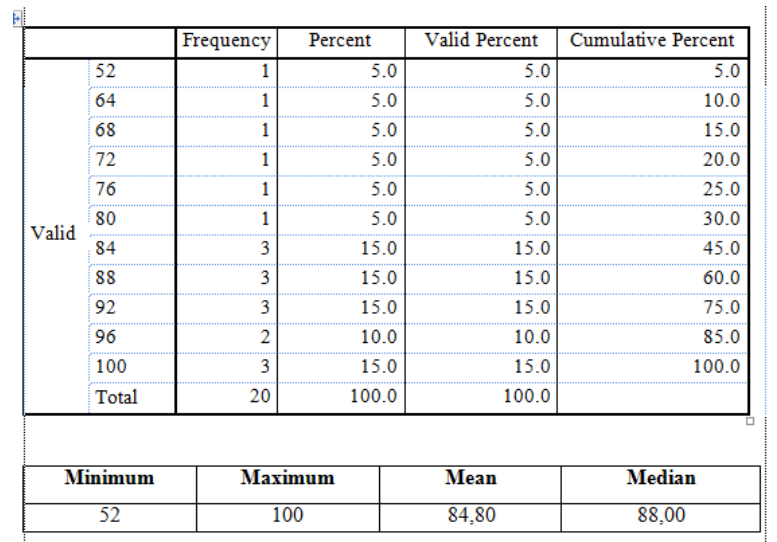

Based on the table above, it is known that the highest frequency is at $84,88,92$ and 100, respectively 3 students with a percentage of $15 \%$ while the lowest frequency is at $52,64,68,72,76$ and 80 as many as 1 student respectively with a 
percentage of $5 \%$. The average of experimental class learning outcomes is 81.50 with the lowest value of 50 and the highest value of 100 .

\subsection{Control Class}

In the control class, the research was carried out by applying a conventional learning model to the VB class. The results were described in the frequency table as follows:

Tabel 3. HasilKelasKontrol

\begin{tabular}{|c|c|c|c|c|c|}
\hline & & Frequency & Percent & Valid Percent & Cumulative Percent \\
\hline \multirow{15}{*}{ Valid } & 48 & 1 & 5.0 & 5.0 & 5.0 \\
\hline & 52 & 2 & 10.0 & 10.0 & 15.0 \\
\hline & 56 & 1 & 5.0 & 5.0 & 20.0 \\
\hline & 58 & 1 & 5.0 & 5.0 & 25.0 \\
\hline & 60 & 2 & 10.0 & 10.0 & 35.0 \\
\hline & 66 & 1 & 5.0 & 5.0 & 40.0 \\
\hline & 68 & 1 & 5.0 & 5.0 & 45.0 \\
\hline & 72 & 2 & 10.0 & 10.0 & 55.0 \\
\hline & 76 & 1 & 5.0 & 5.0 & 60.0 \\
\hline & 78 & 1 & 5.0 & 5.0 & 65.0 \\
\hline & 84 & 2 & 10.0 & 10.0 & 75.0 \\
\hline & 88 & 2 & 10.0 & 10.0 & 85.0 \\
\hline & 92 & 1 & 5.0 & 5.0 & 90.0 \\
\hline & 96 & 2 & 10.0 & 10.0 & 100.0 \\
\hline & Total & 20 & 100.0 & 100.0 & \\
\hline
\end{tabular}

Based on the table above, it is known that the highest frequency is at a value of 70 respectively 6 students with a percentage of $30 \%$ while the lowest frequency is at a value of 50 as many as 2 students with a percentage of $10 \%$. Average control class learning outcomes of 71.50 with the lowest value of 50 and the highest value of 90.

\subsection{Data Analysis}

Data analysis is a process to examine, filter, change and make data modeling to find useful information as clues for researchers to answer the research question.
To find out the difference of learning outcomes between students with the application of cooperative model of market place activity type and students with conventional learning model in Islamic education subjects at SDN 1 Binangga, researchers used the Independent Test sample T-test with the help of SPSS for windows 21.

The basis for decision making of Independent Test Sample T-test using SPSS (Statistical Product and Service Solution) are:

1. If the significance value or sig. (2-tailed) $<0.05$ then, Ho is rejected and $\mathrm{Ha}$ is accepted. It means that there are differences in the learning outcomes of students with cooperative models of market place activity type and conventional learning models.

2. If the significance value or sig. (2-tailed) $<0.05$ then, Ho is rejected and $\mathrm{Ha}$ is accepted. It means that there are differences in the learning outcomes of students with cooperative models of market place activity type and conventional learning models. 
Tabel 4. Independent Test of T-Test Samples

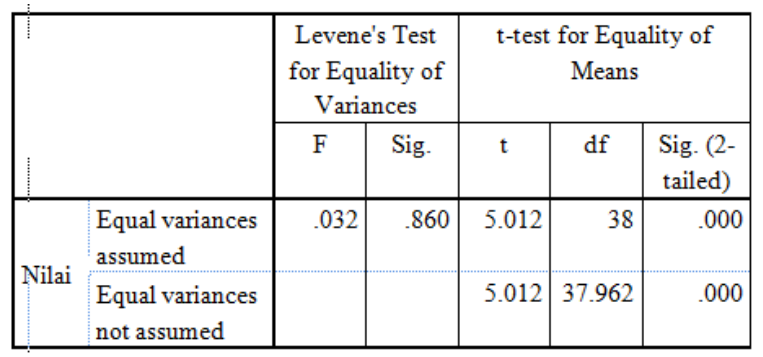

Based on the independent output of the t-test sample above, it is obtained that sig. (2-tailed) value of $0.00<0.05$, then Ho is rejected and $\mathrm{Ha}$ is accepted. It means that, there are differences in the learning outcomes of students with cooperative model of market place activity type and conventional learning model.

Tabel 5. Independent Test of T-Test Samples

\begin{tabular}{|c|c|c|c|c|c|c|}
\hline & & \multicolumn{2}{|c|}{$\begin{array}{c}\text { Levene's Test } \\
\text { for Equality of } \\
\text { Variances }\end{array}$} & \multicolumn{3}{|c|}{ t-test for Equality of Means } \\
\hline & & F & Sig. & $\mathrm{t}$ & $\mathrm{df}$ & $\begin{array}{l}\text { Sig. (2- } \\
\text { tailed) }\end{array}$ \\
\hline $\mathrm{Ni}$ & $\begin{array}{l}\text { Equal } \\
\text { variances } \\
\text { assumed }\end{array}$ & .627 & .433 & 2.380 & 38 & .022 \\
\hline lai & $\begin{array}{l}\text { Equal } \\
\text { variances not } \\
\text { assumed }\end{array}$ & & & 2.380 & 37.174 & .023 \\
\hline
\end{tabular}

Based on the independent output of the sample t-test above, obtained sig. (2tailed) value of $0.02<0.05$, then, $\mathrm{Ho}$ is rejected and $\mathrm{Ha}$ is accepted. It means that there are differences in the learning outcomes of students with cooperative model of market place activity type and conventional learning model.

\subsection{Discussion}

Market Place Activity (MPA) is a type of cooperative learning which focus on learning by working together in groups, where each group member works together in buying and selling information. Cooperative learning is the placement of several students in small groups and assigning them one or several tasks.

This research used an experimental design to find the difference between the experimental class that used the Market Place Activity (MPA) learning model, and the control class with conventional model where Islamic Education teachers only used the lecturing method when delivering learning material.

The research was conducted for three meetings. The main topics discussed in the first meeting is about SurahLuqman verses 1-10. The basic competencies that will be achieved are believing in the story of Luqmanas written in the Quran, understanding and retelling the story, showing humility as an implementation of understanding the exemplary story of Luqman.

The second material is Surah al-Qadr verses 1-5. The basic competencies are reading QS Al Qadr verses 1-5 and understanding then interpreting the verses.

Based on the basic competencies, the researchers made and used a validated test to both experimental and control clases. 
The results of data processing using the IBM SPSS for windows 21 shows that:

\section{First Research}

The independent sample t-test results obtained sig. (2-tailed) value of $0.00<0.05$, then, Ho is rejected and $\mathrm{Ha}$ is accepted. It means that there are differences in the learning outcomes between the students taught using cooperative model of Market Place Activity type and the sudentsusing conventional learning model. This can also be seen from the difference in the average value of the experimental class which is 83.10 and the control class is 63.90 .

\section{Second Research}

The results of the independent sample t-test obtained sig. (2-tailed) values of $0.02<0.05$, then, Ho was rejected and $\mathrm{Ha}$ was accepted. It means that there are differences in the learning outcomes between the students taught using cooperative model of Market Place Activity type and the students using conventional learning model. It can also be seen from the difference in the average value of the experimental class that is 81.50 and the control class is 71.50 .

The independent sample t-test results obtained sig. (2-tailed) value of $0.00<0.05$, then, Ho is rejected and $\mathrm{Ha}$ is accepted. It means that there are differences in the learning outcomes between the students taught using cooperative model of market place activity type and the students using conventional learning model. This can also be seen from the difference in the average value of the experimental class at 84.80 and the control class at 74.30 .

Based on the explanations above it gives an illustration that, learning model using Market Place Activity (MPA) are considered more effective in supporting students' learning outcomes. Using this learning model, students will be more active in the learning process.

\section{Conclusion}

Based on the research results and data analysis conducted by researchers on "Understanding Students' Learning Outcomes Differences Through the Application of the Market Place Activity Type of Cooperative Learning Model and the Application of Conventional Learning Model in Islamic education subjects at SDN 1 Binangga", it can be concluded that:

The result of the first study is that there are differences in learning outcomes between the students taught using cooperative model of market place activity type and the students taught using conventional learning model in Islamic Education subject in SDN 1 Binangga. This can be seen from the value of sig. (2-tailed) of $0.00<0.05$, then, Ho is rejected and $\mathrm{Ha}$ is 
accepted. The second study revealed that there are differences in learning outcomes between the students taught using cooperative model of market place activity type and the students taught using conventional learning model in Islamic Education subject in SDN 1 Binangga. This can be seen from the value of sig. (2-tailed) of $0.02<0.05$, then, Ho is rejected and $\mathrm{Ha}$ is accepted. The third study showed that there are differences in learning outcomes between the students taught using cooperative model of market place activity type and the students taught using conventional learning model in Islamic Education subject in SDN 1 Binangga. This can be seen from the value of sig. (2-tailed) of $0.00<0.05$, then, Ho is rejected and $\mathrm{Ha}$ is accepted.

\section{References}

Ahmad Tafsir, Ilmu Pendidikan Dalam Persfektif Islam, Bandung: PT. Remaja Rosdakarya, 2005.

Ahmadi, Abu \& Noor Salimi, Dasar-Dasar Pendidikan Agama Islam, Jakarta: Bumi

Aksara, 2004.

Ahmadi, Abu dan Nur Uhbiyati, Ilmu Pendidikan, Jakarta: RinekaCipta: 1991.

Andespa, Roni, Metodologi Riset Bisnis, Pekanbaru: Al Huda Press.2012.

Arief, Armai Pengantar ilmu dan Metodologi Pendidikan Islam, Jakarta: Ciputat Press, 2002.
Arikunto, Suharsimi Prosedur Penelitian Suatu Pendekatan Praktik,, Jakarta: Rineka Cipta, 2008.

,Dasar-Dasar Evaluasi Pendidikan, Jakarta: BumiAksara. 2012.

Aunurrahman. Belajar dan Pembelajaran. Bandung :Alfabeta. 2009.

Baharuiddin dan Esa Nur Wahyuni, Teori Belajar dan Pembelajaran, Cet. Ke. III; Jogjakarta: ArRuzz Media, 2010.

Bungin, Burhan, penelitian kualitatif: Komunikasi, ekonomi, kebijakan public, dan ilmu social lainnya, edisiI ; Jakarta: Kencana Prenada Media Group, 2007.

Dalyono, M. Psikologi Pendidikan, Cet. KeIV; Jakarta: RinekaCipta, 2007.

Darajat, Zakiah Metodik Khusus Pengajaran Agama Islam, Jakarta:PT. Bumi Aksara,2008.

Daryanto Dan Raharjo, Muljo. Model Pembelajaran Inovatif. Yogyakarta: Gava Media. 2012.

Departemen Agama RI, Al-Quran dan Terjemahnya, Surabaya: Duta Ilmu, 2002

Departemen Pendidikan Nasional RI, Panduan Penyusunan SilabusJ akarta: Dirjen

Pendidikan Dasar dan Menengah, 2006.

Djaali, Psikologi Pendidikan, Jakarta: BumiAksara, 2008.

Djamarah, Bahri, Syaiful, Psikologi Belajar, Jakarta: PT.RinekaCipta, 2008.

Djamarah, SyaifulBahri, Strategi , Jakarta: PT Rineka Cipta, 2006

Fatmawati. Penerapan Metode Market Place Activity (MPA) Pada Kompetensi Ketentuan Sholat. Jurnal Penelitian Pendidikan Indonesia Vol. 2, No. 2.

Ghozali, Imam ,Aplikasi Analisis Multivariate dengan Program IBM SPSS 19.

Hartono, Metodologi Penelitian, Pekanbaru: Zanafa, 2011.

Arifin, Zainal, Evaluasi Pembelajaran 2 .tp:/www.google.com/amp/s/jorjoran.wordpress. Bandung: Remaja Rosdakarya, 2009. $\frac{\text { com/2016/11/10/implementasi-teknik- }}{\text { com }}$ 
market-place-activity-mpa-learning/amp. Di aksespadatanggal 5 mei 2018

Isjoni, Cooperative Learning Efektivitas Pembelajaran Kelompok, Cet. 7, Bandung: Alfabeta, 2013.

Istarani, Muhammad Ridwan, 50 Tipe Pembelajaran Kooperatif, Medan: Media Persada, 2014.

Kariadinata, Rahayu \& Maman Abdurrahman, Dasar-dasar Statistik Pendidikan, Bandung:Pustaka Setia, 2012.

Komulasari, Kokom, Pembelajaran Kontekstual Konsepdan Aplikasi, Bandung: PT.Refika Aditama, 2010.

Kurikulum 2004, Standar Kompetensi Mata Pelajaran Pendidikan Agama Islam di SMAdan MA, (Jakarta: Depdiknas 2003.

Majid, Abdul dan Dian Andayani, Pendidikan Agama Islam Berbasis Kompetensi, Bandung: Remaja Rosdakarya, 2004.

Majid, Abdul, Belajar Dan Pembelajaran, Bandung :PT Temaja Rosdakarya.

Margono.,Metodologi Penelitian Pendidikan. Jakarta :Rineka Cipta, 2007.

Mujib, Abdul, JusufMudzakkir, Ilmu Pendidkan Islam, Jakarta: Kencana Prenada Media,2006.

Mulyono, M. Anton, Kamus Besar Bahasa Indonesia, Jakarta: Balai Pustaka, 2000.

Nizar, Samsul, Dasar-Dasar Pemikiran Pendidikan Islam, Padang : IAIN IB Press, 2000.

Putra, Nusa, Santi Lisnawati, Penelitian Kualitatif Pendidikan Agama Islam, Bandung: PT Remaja Rosdakarya, 2012.

Ramayulis, Metodologi Pendidikan Agama Islam, Jakarta: Kalam Mulia, 2010.
Riduwan, Belajar Mudah Penelitian GuruKaryawan Peneliti Pemula, Bandung: Alfabeta. 2012.

Metode dan Teknik MenyusunTesis, Bandung: Alfabeta, 2004.

Roy, Perry, Hilton and Charlotte brownlow, SPSS Explained, East Sussex: Routledge, 2004.

Rusman, Model-model Pembelajaran, Jakarta: PT Raja Grafindo Persada, 2011.

Sanjaya, Wina, Kurikulum dan Pembelajaran Teori dan Praktik Pengembangan Kurikulum Tingkat Satuan Pendidikan (KTSP), (Jakarta: Kencana, 2008.

,Pembelajaran Dalam Implementasi Kurikulum Berbasis Kompetensi, Jakarta: Kencana, 2008.

Santoso, Singgih, Mengatasi Berbagai Masalah Statistik dengan SPSS, Jakarta: PT. Media Elexkomputindo, 2003.

Sardiman. Interaksi Motivas iBelajar Mengajar. Jakarta: Rajawali Pers. 2009.

Shaleh, Rachman Abdul, Pendidikan Agama Dan Pembangunan Watak Bangsa, Jakarta: Pt Raja GrafindoPersada, 2005.

Slameto. Belajar dan Faktor-Faktor Yang Mempengaruhinya, Jakarta: PT Rineka Cipta, 2010.

Sofyan, EdydanSantyVirgantyani. Pengaruh Model Pembelajaran Market Place Activity Terhadap Prestasi Belajar Siswa Di SMP PGRI 1 Kota Cimahi. Jurnal ilmiah CISOC. Vol. IV No. 02.

Sudiyono, Ilmu Pendidikan Islam jilid 1, Jakarta: PT RinekaCipta, 2009.

Sudjana, Nana, Penilaian Hasil Proses Belajar Mengajar, PT Remaja Roskarya, Bandung, 2009,

Sugiyono, Metode Penelitian Kuantitatifdan $R \& D$, Bandung: CV. ALFABETA, 2012.

Statistik untuk Penelitian, Bandung: Alfabeta, 2009. 
Sukardi, Metodologi Penelitian Pendidikan, Jakarta, BumiAksara, 2009.

Suprijono, Agus, Cooperative Learning Teori \& Aplikasinya, Yogyakarta: Pustaka Pelajar, 2010.

Sutikno, M. Sobry. Pembelajaran Efektif. Mataram: NTP Press. 2005.

Suryabrata, Sumadi Suryabrata, Metodologi Penelitian, (Cet. XI; Jakarta: PT Raja Grafindo Persada, 2009

Syafaat, Aat, Sohari Sahrani, Muslih, Peranan Pendidikan Agama Islam, Jakarta: PT. Raja Grafindo Persada, 2008.

Syah, Muhibbin, Psikologi Pendidikan dengan Pendekatan Baru, Cet. XV; Bandung:PT. RemajaRosdaKarya, 2010.
SyaifuldanAswan.,Strategi Belajar Mengajar. Jakarta :Rineka Cipta, 2006.

Trianto, Mendesain Model Pembelajaran Inovatif- Progresif, Jakarta: Kencana Prenada Media Group, 2009

The Effect of Type Stad Cooperative Learning Model, the Way of Learning, And Learning Motivation toward Enterpreneurial Attitudes (A case Study in SMK N I Jombang), (Journal of Research \& Method in Education (IOSR-JRME), Volume 3, Issue 5, Nov. -Dec. 2013

Vaus, David D., Analyzing Social Science Date: 50 Key Problems in Date Analysis, Thousand Oaks: Sage Publication, 2002. 